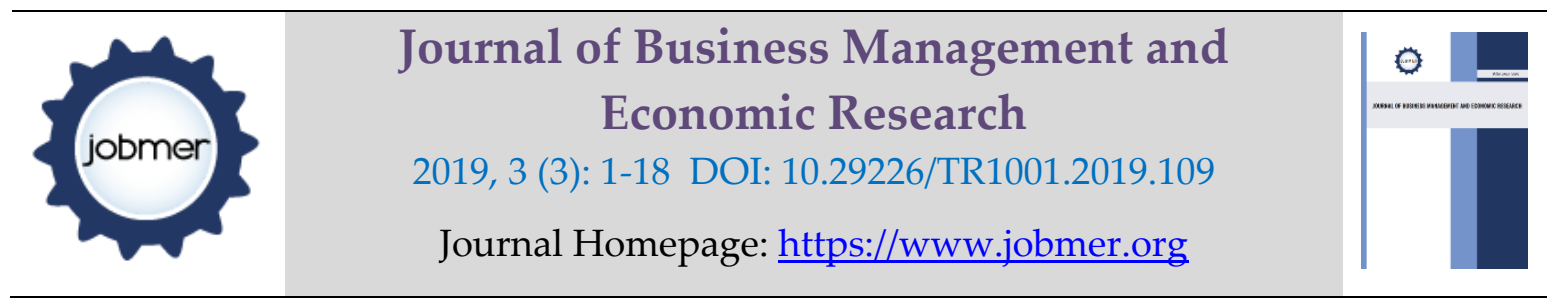

\title{
The Role of Product Innovation in Mediating the Influence of Entrepreneurship Orientation on Marketing Performance (A Study on Silver Craft MSMEs in Celuk, Gianyar)
}

\author{
Ade Mas Dwita Puspa Anjani \\ Faculty of Economics and Business Udayana University, Bali, Indonesia \\ dwithapuspa9f@gmail.com \\ Ni Nyoman Kerti Yasa \\ Faculty of Economics and Business Udayana University, Bali, Indonesia \\ kertiyasa@unud.ac.id
}

\begin{abstract}
The purpose of this study is to determine the role of product innovation in mediating the influence of entrepreneurship orientation on marketing performance. The sampling method used is the total population sampling method. The total sample taken is 70 respondents. The data collection is conducted by using questionnaires which are given to the owners or managers of the silver craft MSMEs in Celuk, Gianyar. The analysis technique utilized is the path analysis technique and the sobel test. The research results show that the product innovation variable is able to significantly mediate the influence of entrepreneurship orientation on marketing performance. Hence, owners of the silver craft MSMEs in Celuk, Gianyar should always improve their product innovation through new product designs, usage of new materials, and the use of new production tools, in order to increase their marketing performance.
\end{abstract}

Keywords: Entrepreneurship Orientation, Product Innovation, Marketing Performance.

\section{Introduction}

Today, with the increasely high competition in the market, along with the implementation of the AEC 2015, firms are demanded to be more aggressive in running their business and marketing their products in their respective industries. Firms must develop and implement the correct strategy to market their products. Marketing is the proccess in which firms create value for customers and 
develop strong relationship with customers, with the purpose to capture the value from customers as the reward (Kotler \& Armstrong, 2014:27).

Each firm certainly has marketing activities to market their products, so that the products are more known to the people. All marketing activities are performed with the purpose to increase the marketing performance which is a measure of the firm's success (Asashi \& Sukaatmadja, 2017). Marketing performance according to Juliana \& Artha Kusuma (2017) is the firm's success in attaining a higher annual sales, greater market share, and increase in the number of consumers through various business or marketing strategies. Aside from implementing the right business strategy, the entrepreneurship orientation culture also needs to be developed continuously so that the marketing performance further improves (Musrifah \& Muwartiningsih, 2017). Entrepreneurship orientation is very important because through the manager's mindset of always desiring innovation, product innovation will be increasingly encouraged.

Firms need to pay attention to their entrepreneurship orientation which can be in the form of proactive attitude, willingness to take risk, and being innovative in order to continuously innovate their products and eventually increase the competitiveness and performance of the product in the business environment (Ryiadi \& Yasa, 2016). Entrepreneurship orientation is an important factor for continuous innovation. To achieve continuous innovation, firms need the managerial abilities to utilize the resources effectively.

Aside from entrepreneurship orientation, there are other factors which influence marketing performance, namely product innovation. Product innovation is the implementation of new ideas, which can be in terms of product, process, marketing, and even the organization to increase customer value and contribute towards firm performance or effectivity (Maslucha \& Sanaji, 2013). Innovation is a process which involves the generation, development and adaptation of new ideas by the firms (Ahimbisibwe et al., 2013). Innovation is a cultural aspect and the firm's acceptance towards new ideas. They introduce their model to the ability to innovate, which is defined as the organization's ability to adopt and implement new ideas, process or products successfully (Prifti \& Alimehmeti, 2017).

This phenomena also occurs in the Silver industry in Celuk, in which a fall in the marketing performance of silver is observed. The decrease in marketing performance of the silver craft MSMEs 
in Celuk, Gianyar can be seen from the silver export value fluctuation of Gianyar Regency, Bali, which is shown in Table 1.1.

Table 1.1 The Silver craft Commodity Export Value of Gianyar Regency, Bali.

\begin{tabular}{cccc}
\hline No & Year & Export Value (USD) & Increase/Decrease (\%) \\
\hline 1 & 2014 & 4.674 .836 & - \\
\hline 2 & 2015 & 2.944 .181 & -37 \\
\hline 3 & 2016 & 3.539 .743 & 20 \\
\hline 4 & 2017 & 3.232 .543 & $-8,6$ \\
\hline 5 & 2018 & 2.422 .192 & -25 \\
\hline \multicolumn{5}{c}{ Average } & -12.6 \\
\hline
\end{tabular}

Source: Disperindag of Gianyar Regency, 2018

According to Dharmana Putra \& Rahanatha (2017), Bali province is known for its various kinds of handcrafts, especially the handcrafts that are known internationally. Among the famous handcrafts in Bali is the silver crafts. This study focuses on the silver craft MSMEs in Celuk Village, Gianyar Regency. Celuk village is located in Gianyar Regency which is a famous center of silver crafts. The art of silver craft in Celuk has existed since around 1915 (Wardana, 2016:74). The glory of the silver craft MSMEs in Celuk has started to decline, especially since the $1^{\text {st }}$ and $2^{\text {nd }}$ Bomb in Bali in year 2002 and 2005 (Wardana, 2016:6).

Based on the pre-survey results conducted on 10 silver craft MSME owners in Celuk, Gianyar, the MSMEs have an unsatisfying marketing performance. The cause is suspected to be because the entrepreneurship orientation and the product innovation conducted by the silver craft MSMEs in Celuk are not optimal. Consequently, further research must be conducted to prove this matter, which is by examining the variables, namely entrepreneurship orientation, product innovation, and marketing performance.

The purposes of this study are: (1) to explain the influence of entrepreneurship orientation on the marketing performance of silver craft MSMEs in Celuk, Gianyar; (2) to explain the influence of entrepreneurship orientation on the product innovation of silver craft MSMEs in Celuk, Gianyar; (3) to explain the influence of product innovation on the marketing performance of silver craft MSMEs in Celuk, Gianyar; and (4) to explain the role of product innovation in mediating the influence of entrepreneurship orientation on the marketing performance ofsilver craft MSMEs in Celuk, Gianyar. 


\section{Literature Review and Hypothesis Development}

Entrepreneurship orientation is the ability of a person to create something new and different which will be seen as unique. Entrepreneurship orientation is the creativity and innovative ability which is the basis and resource needed to search for opportunities towards success (Syukron \& Ngatno, 2016). According to Wardi et al. (2017) entrepreneurship orientation is a firm level characteristic because it reflects the behavior of the firm. More specifically there are three dimensions of entrepreneurship orientation, namely, innovativeness, proactiveness, and the courage to take risks.

Innovation is differentiated into four types, namely product innovation, process innovation, marketing innovation and organizational innovation (Maslucha \& Sanaji, 2017). The variables used in this study is the product innovation, and thus this study discusses product innovation. The product innovation developed is expected to be able to increase the firm's ability in producing high quality products. By producing quality products, firms would be able to improve their product development ability, thus continuous product development can be achieved (Juliana \& Artha Kusuma, 2017). According to Sondari et al. (2013), in performing innovation, firms must attempt to create greater value for consumers by creating new products with a production process better than competitors.

Marketing performance is the improvement in sales based on how far the firm is able to maintain their existing consumers or increase the number of new consumers (Juliana \& Artha Kusuma, 2017).In this current era of high business competition, firms that are able to increase their sales mean that they have a good marketing performance. Djayadningrat et al. (2017) explained that marketing performance is the factor which is frequently used to measure the market achievement of a firm's product.The marketing performance is considered successful if the sales data state that the amount of product sold increase, the number of customers increase, increase in sales, wider market coverage, and the products are more known to the consumers or the people (Mulyani \& Mudiantono, 2015). 


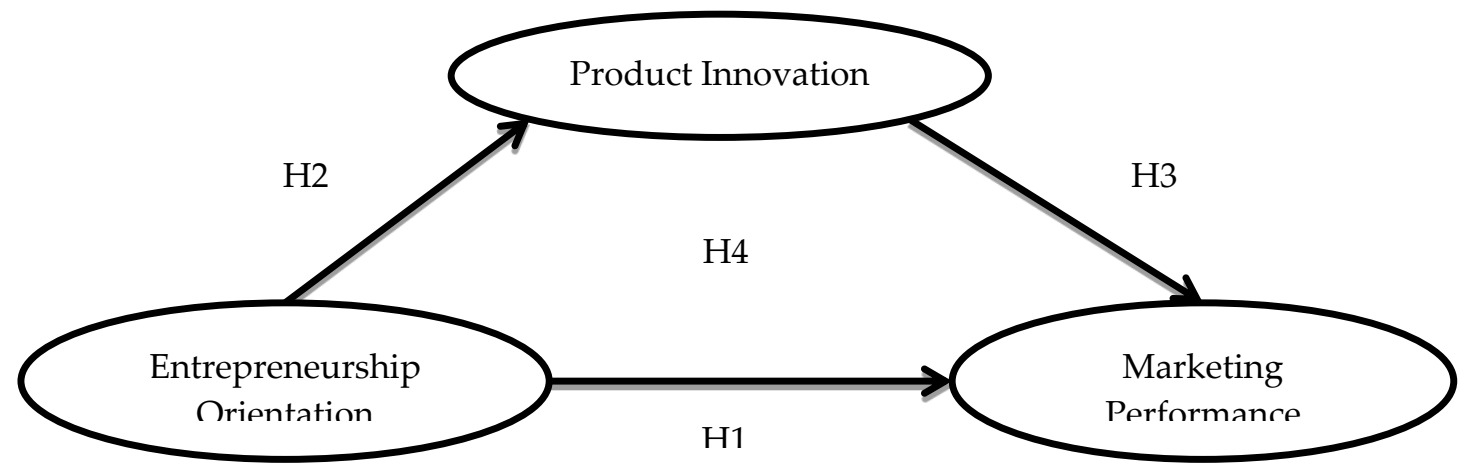

Picture 1. Conceptual Framework

\section{Research Hypothesis}

According to the research by Djayadiningrat et al (2017), the variable of entrepreneurship orientation has a positive and significant influence on marketing performance. The research by Ryiadi \& Yasa (2016) stated that entrepreneurship orientation and product performance has a positive and significant relationship. This means that the greater the entrepreneurship orientation of a business practitioner, the higher the product performance will be. Based on the empirical review, the hypothesis is formulated as follows:

\section{H1 : Entrepreneurship orientation has a positive and significant influence on marketing performance.}

A higher level of entrepreneurship orientation will stimulate more innovation and result in creating new markets (Gradistya \& Farida, 2016). According to the research by Djayadiningrat et al. (2017) entrepreneurship orientation has a positive and significant influence on product innovation. Likewise, according to Priatin et al (2017), entrepreneurship orientation has a positive influence on product innovation. The research result by Gradistya \& Farida (2016) also stated that entrepreneurship orientation has a positive and significant influence on innovation. This is because entrepreneurs have the attitude to be proactive in reaching for the available opportunities. Observing consumers and the market will help the firm in making innovations. Based on the empirical review, the hypothesis can be formulated as follows: 


\section{H2 : Entrepreneurship orientation has a positive and significant influence on product innovation.}

The study conducted by Juliana \& Artha Kusuma (2017) stated that product innovation significantly and positively influences marketing performance. The research by Maklon (2014) revealed that product innovation has a positive and significant influence on marketing performance, which means that the higher the product innovation of a firm in the creative industry, the higher the marketing performance level. The research by Putra \& Rahanatha (2017) stated that product innovation has a positive and significant influence on the marketing performance of silver craft MSMEs in Celuk Village, Gianyar Regency. Based on the empirical review, the following hypothesis is formulated:

\section{H3 : Product innovation has a positive and significant influence on marketing performance.}

Based on the research by Djayadiningrat et al. (2017), the results showed that product innovation is able to significantly mediate entrepreneurship orientation. The research by Ryiadi \& Yasa (2016) stated that innovation ability significantly mediates the influence of entrepreneurship orientation on product performance. Likewise, the research by Priatin et al. (2017) stated that product innovation is able to mediate the influence of entrepreneurship orientation on marketing performance. Based on the empirical review, the hypothesis is formulated as follows:

\section{H4 : Product innovation is able to significantly mediate the influence of entrepreneurship orientation on marketing performance}

\section{Research Method}

This study is categorized as an associative study, which is a study with the purpose to examine the relationship between two or more variables (Sugiyono, 2018:51). This study examines the influence of entrepreneurship orientation on product innovation and marketing performance along with the influence of product innovation on the marketing performance of silver craft MSMEs in Celuk 
Village, Gianyar Regency. The research objects in this study are the entrepreneurship orientation, product innovation, and marketing performance. The population in this study is the silver craft MSMEs in Celuk, Gianyar.

The data collection method utilized in this study is by using questionnaires, in which a number of questions are directed to the respondents to be filled in accordance to the respondent's perception regarding the research objects. The questionnaires are distributed to the owners or managers of the silver craft MSMEs in Celuk, Gianyar. The measurement of the respondent's answers is by using the Likert scale. The data analysis techniques in this study are the classical assumption test and the path analysis.

\section{Results and Discussion}

Table1 Characteristics of Respondents

\begin{tabular}{|c|c|c|c|c|}
\hline No & Variable & Classification & Total (people) & Percentage \\
\hline \multirow{2}{*}{1} & \multirow{2}{*}{ Gender } & Male & 58 & 82,9 \\
\hline & & Female & 12 & 17,1 \\
\hline & Total & & 70 & 100 \\
\hline \multirow{4}{*}{2} & \multirow{4}{*}{ Age (years) } & $18-30$ & 4 & 5,7 \\
\hline & & $31-43$ & 14 & 20 \\
\hline & & $44-56$ & 39 & 55,7 \\
\hline & & $57-70$ & 13 & 18,6 \\
\hline & Total & & 70 & 100 \\
\hline \multirow{2}{*}{3} & \multirow{2}{*}{ Position } & Owner & 61 & 87,1 \\
\hline & & Manager & 9 & 12,9 \\
\hline & Total & & 70 & 100 \\
\hline
\end{tabular}

Source: Computed Primary Data, 2018

Table 1 explains that there are more male respondents than female respondents, in which 82,9 percent are male while 17,1 percent are female. In terms of the age, a majority, 55,7 percent of the respondents have an age of $44-56$ years old, 5,7 percent are in the age group of 18 - 30 years old, 20 percent have an age between 31 - 43 years old, and 18,6 percent have an age of 57 - 70 years old. Based on the position, it can be seen that 61 respondents, or 87,1 percent of the respondents are the owners of the business, while 9 people, or 12,9 percent are the business managers. 
The validity test has a purpose to examine whether the questionnaires are the correct research instrument to measure what should be measured (Sugiyono, 2018:193). An instrument is deemed to be valid if the correlation coefficient value r-calculated is greater than 0,30 (Sugiyono, 2018:198).

Table 2.

The Instrument Validity Test Results for the Entrepreneurship Orientation Variable

\begin{tabular}{|c|c|c|c|}
\hline No & Indicator & rcalculated & Description \\
\hline 1 & $\mathrm{X} 1$ & 0,652 & Valid \\
\hline 2 & $\mathrm{X} 2$ & 0,694 & Valid \\
\hline 3 & X3 & 0,593 & Valid \\
\hline 4 & $X 4$ & 0,540 & Valid \\
\hline 5 & X5 & 0,670 & Valid \\
\hline 6 & X6 & 0,730 & Valid \\
\hline
\end{tabular}

Source: Computed Primary Data, 2018

Table 3.

The Instrument Validity Test Results for the Product Innovation Variable

\begin{tabular}{clcc}
\hline No & Indicator & rcalculated & Description \\
\hline 1 & Y1.1 & 0,603 & Valid \\
2 & Y1.2 & 0,671 & Valid \\
3 & Y1.3 & 0,729 & Valid \\
\hline
\end{tabular}

Source: Computed Primary Data, 2018

Table 4.

The Instrument Validity Test Results for the Marketing Performance Variable

\begin{tabular}{clcc}
\hline No & Indicator & rcalculated & Description \\
\hline 1 & Y2.1 & 0,712 & Valid \\
2 & Y2.2 & 0,702 & Valid \\
3 & Y2.3 & 0,702 & Valid \\
4 & Y2.4 & 0,747 & Valid \\
5 & Y2.5 & 0,761 & Valid \\
\hline
\end{tabular}

Source: Computed Primary Data, 2018

The reliability test is used to examine the research instruments. The test is used to examine the accuracy of the questionnaire answers in different time periods. A questionnaire is deemed as reliable if the a person's answer towards a question is consistent or stable from time to time, with a Cronbach's Alpha value of $>0,60$ (Ghozali, 2013:47).

Table 5. The Reliability Test Results for the Research Instruments

\begin{tabular}{lcc}
\multicolumn{1}{c}{ Variable } & Alpha Cronbach & Description \\
\hline Entrepreneurship Orientation & 0,747 & Reliable \\
\hline Product Innovation & 0,750 & Reliable \\
\hline
\end{tabular}




\begin{tabular}{lcc}
\hline Marketing Performance & 0,782 & Reliable \\
\hline Source: Computed Primary Data, 2018 & &
\end{tabular}

The data description in this study discusses the perception of respondents towards the variables of entrepreneurship orientation, product innovation, and the marketing performance attained through distributing questionnaires. The quantitative assessment is done by using the interval scale and integrating the average score according to the assessment categories. The frequency distribution needs to be determined in order to provide a description of respondent's assessment regarding the research variables (Wirawan, 2014: 33).

Based on the data tabulation results, respondent's answers toward the 6 statements regarding entrepreneurship orientation of the entrepreneur was answered by 70 respondents, and the tabulation of the total answers of all respondents for each category is displayed in Table 6.

Table 6. Description of Respondent's Answers Regarding Their Assessmentsonthe Entrepreneurship Orientation Variable

\begin{tabular}{|c|c|c|c|c|c|c|c|c|c|}
\hline \multirow[t]{2}{*}{ No. } & \multirow{2}{*}{$\begin{array}{c}\text { Statements for } \\
\text { Entrepreneurship Orientation } \\
(\mathrm{X} 1)\end{array}$} & \multicolumn{5}{|c|}{$\begin{array}{l}\text { Respondent's } \\
\text { Answers }\end{array}$} & \multirow[t]{2}{*}{$\begin{array}{l}\text { Ttl. } \\
\text { Res. }\end{array}$} & \multirow[t]{2}{*}{$\begin{array}{l}\text { Ave- } \\
\text { rage }\end{array}$} & \multirow[t]{2}{*}{ Desc } \\
\hline & & 1 & 2 & 3 & 4 & 5 & & & \\
\hline 1 & $\begin{array}{l}\text { The firm must be willing to } \\
\text { take on failure risks,may it be } \\
\text { small or even big (X.1) }\end{array}$ & 0 & 2 & 1 & 38 & 29 & 70 & 4,34 & $\begin{array}{l}\text { Very } \\
\text { High }\end{array}$ \\
\hline 2 & $\begin{array}{l}\text { The firm always create new } \\
\text { products that provide value } \\
\text { for new or existing } \\
\text { customers.(X.2) }\end{array}$ & 0 & 2 & 1 & 34 & 33 & 70 & 4,40 & $\begin{array}{l}\text { Very } \\
\text { High }\end{array}$ \\
\hline 3 & $\begin{array}{l}\text { The firm must always search } \\
\text { for ways to face the firm's risk } \\
\text { (X.3) }\end{array}$ & 0 & 0 & 3 & 37 & 30 & 70 & 4,39 & $\begin{array}{l}\text { Very } \\
\text { High }\end{array}$ \\
\hline 4 & $\begin{array}{l}\text { The firm accepts significant } \\
\text { failure risks for the sake of } \\
\text { firm growth (X.4) }\end{array}$ & 0 & 5 & 20 & 33 & 12 & 70 & 3,74 & High \\
\hline 5 & $\begin{array}{l}\text { The firm always introduce } \\
\text { new products before } \\
\text { competitors do (X.5) }\end{array}$ & 0 & 0 & 3 & 21 & 46 & 70 & 4,61 & $\begin{array}{l}\text { Very } \\
\text { High }\end{array}$ \\
\hline 6 & $\begin{array}{l}\text { The firm always search for } \\
\text { new markets to target (X.6) }\end{array}$ & 0 & 2 & 0 & 29 & 39 & 70 & 4,50 & $\begin{array}{l}\text { Very } \\
\text { High }\end{array}$ \\
\hline & Averag & & & & & & & 4,33 & $\begin{array}{l}\text { Very } \\
\text { High }\end{array}$ \\
\hline
\end{tabular}

Source: Computed Primary Data, 2018 
The data in Table 6 shows that the 6 questions regarding entrepreneurship orientation attained an average value of 4,33 and is categorized in the category of $4,20-5,00$, or very high. This means that the silver craft MSME owners in Celuk, Gianyar who become the respondents in this study have very high entrepreneurship orientations.

Table 7. Description of Respondents' Answers Regarding Their Assessment on the Product Innovation Variable

\begin{tabular}{|c|c|c|c|c|c|c|c|c|c|}
\hline \multirow[t]{2}{*}{ No. } & \multirow{2}{*}{$\begin{array}{l}\text { Statements for Product } \\
\text { Innovation (Y1) }\end{array}$} & \multicolumn{5}{|c|}{$\begin{array}{l}\text { Respondent's } \\
\text { Answers }\end{array}$} & \multirow[t]{2}{*}{$\begin{array}{l}\text { Ttl. } \\
\text { Res. }\end{array}$} & \multirow[t]{2}{*}{$\begin{array}{l}\text { Ave- } \\
\text { rage }\end{array}$} & \multirow[t]{2}{*}{ Desc } \\
\hline & & 1 & 2 & 3 & 4 & 5 & & & \\
\hline 1 & $\begin{array}{l}\text { The firm routinely creates new } \\
\text { product design and ideas(Y1.1) }\end{array}$ & 0 & 0 & 2 & 18 & 50 & 70 & 4,69 & $\begin{array}{l}\text { Very } \\
\text { Good }\end{array}$ \\
\hline 2 & $\begin{array}{l}\text { The firm uses new materials in } \\
\text { producing products }(Y 1.2)\end{array}$ & 0 & 5 & 13 & 38 & 14 & 70 & 3,87 & Good \\
\hline 3 & $\begin{array}{l}\text { The firm produces products } \\
\text { usingthe most advance } \\
\text { production tools (Y1.3) }\end{array}$ & 0 & 6 & 11 & 41 & 12 & 33 & 3,84 & Good \\
\hline & Averag & & & & & & & 4,13 & Agree \\
\hline
\end{tabular}

Source: Computed Primary Data, 2018

Table 7 shows that the 3 statements regarding product innovation attained an average value of 4,13 and is categorized in the value category of $3,40-4,19$, or very good. This means that the owners of the silver craft MSMEs in Celuk, Gianyar who become the respondents in this study have been conducting product innovation.

Table 8. Description of Respondents' Answers Regarding Their Assessment on the Marketing Performance Variable

\begin{tabular}{|c|c|c|c|c|c|c|c|c|c|}
\hline \multirow[t]{2}{*}{ No. } & \multirow{2}{*}{$\begin{array}{l}\text { Statement for Marketing } \\
\text { Performance (Y2) }\end{array}$} & \multicolumn{5}{|c|}{$\begin{array}{l}\text { Respondent's } \\
\text { Answers }\end{array}$} & \multirow[t]{2}{*}{$\begin{array}{l}\text { Ttl. } \\
\text { Res. }\end{array}$} & \multirow[t]{2}{*}{$\begin{array}{l}\text { Ave- } \\
\text { rage }\end{array}$} & \multirow[t]{2}{*}{ Desc. } \\
\hline & & 1 & 2 & 3 & 4 & 5 & & & \\
\hline 1 & $\begin{array}{l}\text { The firm experiences a sales } \\
\text { growth tendency from year to } \\
\text { year (Y2.1) }\end{array}$ & 0 & 4 & 11 & 46 & 9 & 70 & 3,86 & Good \\
\hline 2 & $\begin{array}{l}\text { The firm is able to increase the } \\
\text { market share from year to year } \\
\text { (Y2.2) }\end{array}$ & 0 & 2 & 10 & 42 & 16 & 70 & 4,03 & Good \\
\hline 3 & $\begin{array}{l}\text { The firm is able to increase the } \\
\text { number of customers from } \\
\text { year to year (Y2.3) }\end{array}$ & 0 & 7 & 4 & 34 & 25 & 70 & 4,10 & Good \\
\hline
\end{tabular}




\begin{tabular}{lllllllllll}
\hline 4 & $\begin{array}{l}\text { The firm is able to expand the } \\
\text { market coverageof their } \\
\text { products (Y2.4) }\end{array}$ & 0 & 3 & 10 & 41 & 16 & 70 & 4,00 & Good \\
\hline $\begin{array}{l}\text { The firm has the tendency of } \\
\text { an increasing profit from year } \\
\text { to year (Y2.5) }\end{array}$ & 0 & 4 & 13 & 37 & 16 & 70 & 3,93 & Good \\
\hline \multicolumn{1}{c}{ Average } & & & & 3,98 & Good \\
\hline
\end{tabular}

Source: Computed Primary Data, 2018

Table 8 shows that the 5 statements regarding marketing performance attained an average value of 3,98 and is categorized in the value category of $3,40-4,19$, or good. This means that the silver craft MSMEs in Celuk, Gianyar, who are the respondents in this study already have a good marketing performance.

From Table 9, it can be seen that the Kolmogorov-SmirnovAsymp.Sig. (2-tailed) value is 0,093. The results indicate that the regression equation model is normally distributed because the KolmogorovSmirnovAsymp. Sig. (2-tailed) value is greater than 0,05.

Table 9. Structure 1 Normality Test Results

\begin{tabular}{lc}
\hline & Unstandardized Residual \\
\hline $\mathrm{N}$ & 70 \\
\hline Kolmogorov-Smirnov & 0,093 \\
Asymp. Sig. (2-tailed) & \\
\hline
\end{tabular}

Source: Computed Primary Data, 2018

Table 10. Structure 2 Normality Test Results

\begin{tabular}{lc}
\hline & Unstandardized Residual \\
\hline $\mathrm{N}$ & 70 \\
\hline Kolmogorov-Smirnov & 0,060 \\
Asymp. Sig. (2-tailed) & \\
\hline
\end{tabular}

Source: Computed Primary Data, 2018

From Table 10, it can be seen that the Kolmogorov-Smirnov Asymp. Sig. (2-tailed) value is 0,060. This result indicates that the regression equation model is normally distributed because the KolmogorovSmirnov Asymp. Sig. (2-tailed) value is greater than 0,05.

Table 11. Multicollinearity Test Results

\begin{tabular}{llcc}
\hline \multicolumn{1}{c}{ Structure Equation } & \multicolumn{1}{c}{ Variable } & Tolerance & VIF \\
\hline $\mathrm{Y}_{1}=\beta_{2} \mathrm{X}+\mathrm{e}_{1}$ & $\begin{array}{l}\text { Entrepreneurship } \\
\text { Orientation }(\mathrm{X})\end{array}$ & 1,000 & 1,000 \\
\hline $\mathrm{Y}_{2}=\beta_{3} \mathrm{Y}_{1}+\beta_{1} \mathrm{X}+\mathrm{e}_{2}$ & $\begin{array}{l}\text { Entrepreneurship } \\
\text { Orientation }(\mathrm{X})\end{array}$ & 0,546 & 1,832 \\
\cline { 2 - 4 } & Product Innovation $\left(\mathrm{Y}_{1}\right)$ & 0,546 & 1,832 \\
\hline
\end{tabular}


Source: Computed Primary Data, 2018

From Table 11, it can be seen that the tolerance value and the VIF of the entrepreneurship orientation and product innovation variable are greater than $10 \%$ for the tolerance value, and less than 10 for the VIF. This means that the regression equation is free of any multicollinearity.

Table 12. Structure 1 Heteroscedasticity Test Results

\begin{tabular}{llccccc}
\hline & \multicolumn{5}{c}{ Standardized } \\
Model & Unstandardized Coefficients & Coefficients & $t$ & Sig. \\
\cline { 2 - 6 } & B & Std. Error & Beta & \\
\hline 1 & (Constant) & 0,240 & 0,717 & & 0,335 & 0,739 \\
\cline { 2 - 6 } & $\begin{array}{l}\text { Entrepreneurship } \\
\text { Orientation }\end{array}$ & 0,028 & 0,027 & 0,121 & 1,007 & 0,318 \\
\hline
\end{tabular}

Source: Computed Primary Data, 2018

In Table 12, it can be seen that the significance value of the entrepreneurship orientation variable is 0,318 . This value is greater than 0,05 , which means that the independent variable does not have any influence on the absolute residual. Thus, the model formulated does not contain any heteroscedasticity.

Table 13. Structure 2 Heteroscedasticity Test Results

\begin{tabular}{llccccc}
\hline & \multicolumn{2}{c}{$\begin{array}{c}\text { Unstandardized } \\
\text { Coefficients }\end{array}$} & $\begin{array}{c}\text { Standardized } \\
\text { Coefficients }\end{array}$ & $\mathrm{t}$ & Sig. \\
\cline { 2 - 7 } Model & $\mathrm{B}$ & Std. Error & Beta & & \\
\hline 2 & 1,092 & 1,368 & & 0,798 & 0,427 \\
\cline { 2 - 7 } & $\begin{array}{l}\text { (Constant) } \\
\text { Entrepreneurship } \\
\text { Orientation }\end{array}$ & 0,021 & 0,067 & 0,051 & 0,309 & 0,759 \\
\hline \multicolumn{2}{c}{ Product Innovation } & 0,002 & 0,129 & 0,002 & 0,013 & 0,989 \\
\hline
\end{tabular}

Source: Computed Primary Data, 2018

From Table 13, it can be seen that the significance value of the entrepreneurship orientation variable is 0,759 and for the product innovation variable it is 0,989 . These values are greater than 0,05 , which means that both independent variables do not have any influence on the absolute residual. Thus, the model created does not contain any heteroscedasticity. 
Table 14. Results of Path Analysis 1

\begin{tabular}{lccccc}
\hline \multicolumn{1}{c}{ Variable } & Unstandardized Coefficients & $\begin{array}{c}\text { Standardi } \\
\text { zed } \\
\text { Coefficien } \\
\text { ts }\end{array}$ & $\begin{array}{c}\mathrm{t}- \\
\text { calculate }\end{array}$ & $\mathrm{t}$ testSig. \\
\hline B & Std. Error & Beta & \\
\hline (Constant) & 3,295 & 1,219 & & 2,704 & 0,009 \\
\hline $\begin{array}{l}\text { Entrepreneurship } \\
\text { Orientation }(X)\end{array}$ & 0,350 & 0,047 & 0,674 & 7,523 & 0,000 \\
\hline R Square & 0,454 & & & & \\
\hline F Statistics & 56,600 & & & & \\
\hline F test significance & 0,000 & & & \\
\hline
\end{tabular}

Source: Computed Primary Data, 2018

Based on the path analysis results of substructure 1, such as displayed in Table 14, the structural equation can be formulated as follows:

$$
\begin{aligned}
& \mathrm{Y} 1=\beta_{1} \mathrm{X}+\mathrm{e}_{1} \\
& \mathrm{Y} 1=0,674 \mathrm{X}+\mathrm{e}_{1}
\end{aligned}
$$

\begin{tabular}{|c|c|c|c|c|c|}
\hline \multirow[t]{2}{*}{ Variable } & \multicolumn{2}{|c|}{$\begin{array}{c}\text { Unstandardized } \\
\text { Coefficients }\end{array}$} & \multirow{2}{*}{$\begin{array}{c}\begin{array}{c}\text { Standardized } \\
\text { Coefficients }\end{array} \\
\text { Beta }\end{array}$} & \multirow[t]{2}{*}{$\begin{array}{c}\mathrm{t}- \\
\text { calculate }\end{array}$} & \multirow[t]{2}{*}{$\begin{array}{l}\mathrm{t} \text { test } \\
\text { Sig. }\end{array}$} \\
\hline & $\mathrm{B}$ & Std. Error & & & \\
\hline (Constant) & 0,528 & 2,261 & & 0,234 & 0,816 \\
\hline $\begin{array}{l}\text { Entrepreneurship } \\
\text { Orientation }(X)\end{array}$ & 0,490 & 0,111 & 0,502 & 4,413 & 0,000 \\
\hline Product Innovation (Y1) & 0,537 & 0,214 & 0,286 & 2,510 & 0,014 \\
\hline R Square & 0,527 & & & & \\
\hline F Statistics & 37,291 & & & & \\
\hline F test significance & 0,000 & & & & \\
\hline
\end{tabular}

Table 15. Results of Path Analysis 2

Source: Computed Primary Data, 2018

Based on the path analysis results of substructure 2, which is displayed in Table 15, the structural equation can be formulated as follows:

$$
\begin{aligned}
\mathrm{Y}_{1}=\beta_{2} \mathrm{X}+\beta_{3} \mathrm{M}+\mathrm{e}_{2} \\
\mathrm{Y}_{1}=0.502 \mathrm{X}+0.286 \mathrm{Y}_{1}+\mathrm{e}_{2}
\end{aligned}
$$

Based on the substructure model 1 and 2, the final path diagram can be formed. Before designing the final path diagram, the standard error value must be calculated, which is shown as follows:

$$
\begin{aligned}
& \mathrm{Pe}_{\mathrm{i}}=\sqrt{1-\mathrm{R}_{\mathrm{I}}{ }^{2}} \\
& \mathrm{Pe}_{1}=\sqrt{1-{R_{1}}^{2}}=\sqrt{1-0,454}=0,739
\end{aligned}
$$




$$
\mathrm{Pe}_{2}=\sqrt{1-R_{2}{ }^{2}}=\sqrt{1-0,527}=0,688
$$

Based on the calculation of the error influence $\left(\mathrm{Pe}_{1}\right)$, the result of the error influence $\left(\mathrm{Pe}_{1}\right)$ is 0,739 and the error influence $\left(\mathrm{Pe}_{2}\right)$ is 0,688 . The total determination coefficient is calculated as follows:

$$
\begin{aligned}
& \mathrm{R}^{2} \mathrm{~m} \quad=1-\left(\mathrm{Pe}_{1}\right)^{2}\left(\mathrm{Pe}_{2}\right)^{2} \\
& =1-(0,739)^{2}(0,688)^{2} \\
& =1-(0,546)(0,473) \\
& =1-0,258=0,742
\end{aligned}
$$

The total determination coefficient is 0,742 , which means that $74,2 \%$ of the marketing performance variation is influenced by entrepreneurship orientation and product innovation, while the remaining $25,8 \%$ is explained by other factors that are not included in this model.

To examine the mediator variable, whether it mediates the relationship between the independent and dependent variable, the following calculations are conducted:

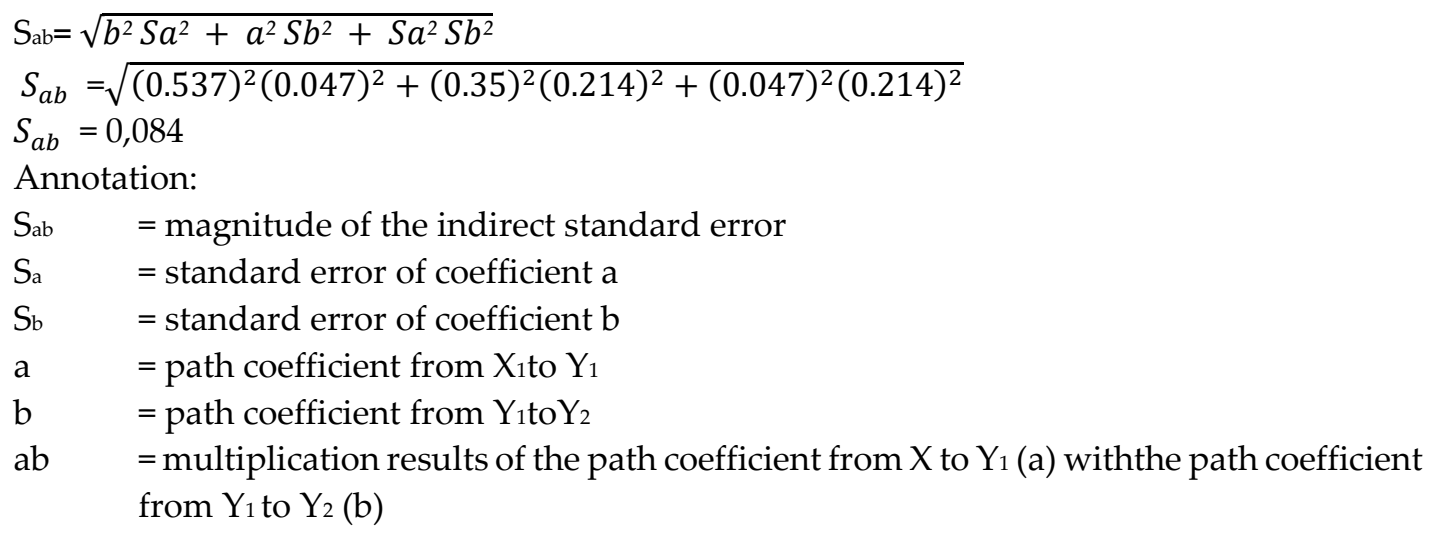

To examine the significance of the indirect influence, the $z$-value of coefficient ab is calculated with the formula shown below :

$$
\begin{aligned}
& Z=\frac{a b}{S a b} \\
& Z=\frac{(0,35)(0,537)}{0,084} \\
& Z=2,216 .
\end{aligned}
$$

The calculation results in Table 15 reveal that the significance level of entrepreneurship orientation is $0,000<0,05$ with a beta value of 0,502 . Thus, research hypothesis $\mathrm{H}_{1}$ is accepted. This means that entrepreneurship orientation has a positive and significant influence on the marketing performance of silver craft MSMEs in Celuk, Gianyar. The calculation results in Table 14 found that the significance 
level of entrepreneurship orientation is $0,000<0,05$ with a beta value of 0,674 . Hence, research hypothesis $\mathrm{H}_{2}$ is accepted. This means that entrepreneurship orientation has a positive and significant influence on the product innovation of silver craft MSMEs in Celuk, Gianyar. The calculation results in Table 15 reveal that the significance level of product innovation is $0,014<0,05$ with a beta value of 0,286 . Hence, research hypothesis $\mathrm{H}_{3}$ is accepted. This means that product innovation has a positive and significant influence on the marketing performance of silver craft MSMEs in Celuk, Gianyar. The calculation results can be attained by comparing the Z-calculated value with the Z-table, in which Zcalculated is 2,216 $>$ Z-table 1,96. Thus, research hypothesis $\mathrm{H}_{4}$ is accepted. This means that product innovation is able to significantly mediate the influence of entrepreneurship orientation on marketing performance.

\section{Conclusion}

Based on the research analysis results and the discussion results in the previous chapters, the conclusions that can be made from this study are as follows. First, entrepreneurship orientation has a positive and significant influence on the marketing performance of silver craft MSMEs in Celuk, Gianyar. This means that with a higher entrepreneurship orientation within the firm, there will be a higher level of marketing performance. Second, entrepreneurship orientation has a positive and significant influence on the product innovation of silver craft MSMEs in Celuk, Gianyar. This means that a higher level of entrepreneurship orientation will stimulate a higher degree of innovation and entails the creation of new markets, thus improving product innovation. Third, product innovation has a positive and significant influence on the marketing performance of silver craft MSMEs in Celuk, Gianyar. This means that the better the product innovation of the firms in the creative industry, the higher the level of marketing performance resulted. Fourth, product innovation is able to significantly mediate the influence of entrepreneurship orientation on marketing performance. This means that the entrepreneurship orientation within the firm has an impact on the firm's ability to innovate products, which can increase the marketing performance of the silver craft MSMEs in Celuk, Gianyar.

Based on the research analysis results, discussion, and conclusions, there are several advices that can be conveyed to the firms, specifically to the owner or managers of the silver craft MSMEs in Celuk, 
Gianyar. First, the owners of the silver craft MSMEs in Celuk, Gianyar needs to understand the impact of the risks they face. If the risks can be identified, the firm can manage their risks well to make it become opportunities. Second, silver craft MSMEs in Celuk, Gianyar needs to start using the most advanced production tools, considering the demand of consumers that continuously change.One is by using molds in which the molds are usually used to create alpaka and xuping. This can be the solution to replacing silver materials which has started to become very expensive. The cost and selling price of alpaka and xuping materials are much cheaper, which could increase consumerdemand. Third, the owners of silver craft MSMEs in Celuk, Gianyar should design and create strategies that are more entrepreneurship oriented to innovate their product, which will eventually result in a greater marketing performance.

\section{References}

Adelina, Agnes, Lapian, James Massie, Imelda Ogi. (2016). “Pengaruh Orientasi Pasar Dan Inovasi Produk Terhadap Kinerja Pemasaran Pada PT. BPR Prisma Dana Amurang".Jurnal EMBA: Jurnal Riset Ekonomi, Manajemen, Bisnis dan Akuntansi,4 (1), hal. 1330-1339.

Ahimbisibwe, Godwin M., Joseph M. Ntayi, Muhammed Ngoma .(2013). “Export Market Orientation, Innovation, And Performance Of Fruit Exporting Firm In Uganda".European Scientific Journal, 9 (4), pp. 295-313.

Altuntas, Gultekin, Fatih Semercioz, Hanife Eregez. (2013). “Linking Strategic And Market Orientations To Organizational Performance: The Role Of Innovation In Private Healthcare Organizations". Procedia - Social Behavioral Sciences, 99 (9), pp. 413-419.

Arief, Mohammad, Armanu Thoyib, Achmad Sudiro, Fatchur Rohman. (2013). "The Developing Framework On The Relationship Between Market Orientation And Entrepreneurial Orientation To The Firm Performance Through Strategic Flexibility: A Literature Perspective". European Journal Of Business And Management, 5 (9), pp. 136-150.

Asashi, Tesa and I Putu Gede Sukaatmadja. (2017).“Peran Inovasi Produk Dalam Memediasi Pengaruh Orientasi Pasar Terhadap Kinerja Pemasaran”.E - Jurnal Manajemen Unud, 6 (4), hal.1816-1845.

Atalay, Murat, Nilgun Anafarta, Fulya Sarvan. (2013). "The Relationship BetweenInnovation and Firm Performance: An Empirical Evidence From Turkish Automotive Supplier Industry". Procedia - Social and Behavioral Science, 75, pp. 226-235.

Cahyo, Roberto Junianto, Dhyah Harjanti. (2013). "Analisa Inovasi Produk Pada Sektor Usaha Formal Dan Informal di Jawa Timur".AGORA, 1 (3), hal.1542-1546.

Cynthia Vanessa Djodjobo, Hendra N. Tawas. (2014). "Pengaruh Orientasi Kewirusahaan, Inovasi Produk, Dan Keunggulan Bersaing Terhadap Kinerja Pemasaran Usaha Nasi Kuning di Kota Manado".Jurnal EMBA, 2 (3), hal. 1214-1224

Dewi Sondari, Syamsul Maarif, Yandra Arkeman. (2013). “Analisis Faktor Yang Mempengaruhi Inovasi Produk Nanoenkapsulasi Ekstrak Pegagan Sebagai Sediaan Untuk Mengatasi Selulit".Jurnal Teknik Industri, 3 (1), hal.54-63. 
Dharmana Putra, I Gede, Gede Bayu Rahanatha. (2017). “Peran Inovasi Produk Memediasi Orientasi Pasar Terhadap Kinerja Pemasaran".E - Jurnal Manajemen Unud, 6 (8), hal. 43614390.

Djayadiningrat, Adinda Fauziyyah, I Putu Gde Sukaatmadja, Ni Nyoman Kerti Yasa. (2017).

“Peran Inovasi Produk Memediasi Orientasi Kewirausahaan Terhadap KinerjaPemasaran IMK Sektor Industri Makanan Kota Denpasar".E - Jurnal Manajemen Unud, 6 (9), hal. 4978-5004.

Ghozali, Imam. (2013). Aplikasi Analisis Multivariate dengan Program SPSS.Edisi Ketujuh.Semarang: Badan Penerbit Universitas Diponegoro

Gozali, Imam, Asta Nugraha. (2015). “Analisis Kinerja Pemasaran Untuk Mencapai Keunggulan Bersaing (Studi Pada Centra Industri Pakaian Batik Di Pekalongan)".Prosiding Seminar Nasional \& Call For Papers, hal.108-122.

Gradistya, Giska Ova, Naili Farida. (2016). “Pengaruh Orientasi Pasar Dan Orientasi Kewirausahaan Terhadap Kinerja Pemasaran Melalui Inovasi Sebagai Variabel Intervening ". Jurnal Ilmu Administrasi Bisnis, 5 (3), hal. 127- 135.

Helia, Renita, Naili Farida, Bulan Prabawani. (2015). “Pengaruh Orientasi Pasar dan Orientasi Kewirausahaan Terhadap Keunggulan Bersaing Melalui Inovasi Produk Sebagai Variabel Antara (Studi Kasus Pada IKM Batik di Kampung Batik Laweyan, Solo)".Journal Of Social And Political Of Science, hal. 1 - 11.

Juliana, Made Mahayu, Artha Kusuma. (2017). "Peran Inovasi Produk Memediasi Orientasi Pasar Terhadap Kinerja Pemasaran Pada Fashion Retail di Kota Denpasar".E - Jurnal Manajemen Unud, 6 (9), hal.5005-5031.

Kotler, Philip, Gary Armstrong. (2014). Principle OfMarketing, 15th edition.New Jersey: Pearson Prentice Hall.

Maklon Felipus Killa. (2014). "Effect of Entrepreneurial Innovativeness Orientation, Product Innovation, and Value Co-Creation on Marketing Performance". Journal Of Research In Marketing, 2 (3), pp. 198-204.

Mamun, Abdullah, Muhammad Mohiuddin, Syed Ali Fazal, Ghazali Bin Ahmad. (2018). “Effect Of Entrepreneurial And Market Orientation On Consumer Engagement And Performance Of Manufacturing SMEs". Management Research Review, 41 (1), pp. 133147.

Maruta, I.G.N. Anom, R. Andi Sularso, Nanis Susanti. (2017). “The Effect of Market Orientation, Entrepreneurship Orientation, and Imitation Strategy on Competitive Advantage (Study on SME of Leather Bag and Suitcase in East Java)"..International Journal of Business and Management Invention, 6 (7), pp. 24-35.

Maslucha, Nur'aini, Sanaji. (2013). “Pengaruh Orientasi Pasar Terhadap Kinerja Pemasaran Melalui Inovasi".Jurnal Ilmu Manajemen, 1 (4), hal.1-12.

Merakati, Indah, Rusdarti, Wahyono. (2017). "Pengaruh Orientasi Pasar, Inovasi, Orientasi Kewirausahaan Melalu Keunggulan Bersaing Terhadap Kinerja Pemasaran".Journal Of Economic Education, 6 (2), hal.114-123.

Mulyani, Ida Tri, Mudiantono. (2015). “Upaya Meningkatkan Kinerja Pemasaran Melalui Orientasi Pasar Dan Orientasi Kewirausahaan Dengan Inovasi Sebagai Variabel Intervening (Studi Empiris Pada Usaha Mikro Kecil Menengah Kota Semarang)". Diponegoro Journal Of Management, 4 (3), hal. $\quad$ 1-12.

Murni, Tri, Taher Alhansji, M. Syafi'ie Idrus, Zainul Arifin. (2014). “The Effect Of Entrepreneurial Orientation On The Management Capability And Sustainable Innovation (Study On 
Batik Small And Medium Enterprise in East Java Indonesia". IOSR Journal Of Business And Management (IOSR-JBM), 16 (4), pp. 16-20.

Musrifah, Murwatiningsih. (2017). "Pengaruh Orientasi Pasar Dan Orientasi Kewirausahaan Terhadap Kinerja Pemasaran Melalui Keunggulan Bersaing".Management Analysis Journal, 6 (4), hal.495-505.

Narastika, A.A. Rai, Ni Nyoman Kerti Yasa. (2017). “Peran Inovasi Produk Dan Keunggulan

Bersaing Memediasi Pengaruh Orientasi Pasar Terhadap Kinerja Pemasaran".Jurnal Ilmu Manajemen, 7 (1), hal.1-20.

Pardi, Suharyono, Suyadi Imam, Arifin Zainul. (2014). “The Effect of Market Orientation and Entrepreneurial Orientation toward Learning Orientation, Innovation, Competitive Advantages and Marketing Performance".European Journal of Business and Management, 6 (21), hal.69-80.

Priatin, Yusri, Djasuro Surya, Indra Suhendra. (2017). “Pengaruh Orientasi Pasar dan Orientasi Kewirausahaan Terhadap Kinerja Pemasaran Dengan Inovasi Produk Sebagai Variabel Intervening".Jurnal Riset Bisnis dan Manajemen Tirtayasa (JRBMT), 1 (1), hal.81-96.

Prifti, Rezart, Genc Alimehmeti. (2017). "Market orientation, Innovation, And FirmPerformanceAn Analysis Of Albanian Firms". Journal OfInnovation And Enterpreneurship, 6 (8), pp. 1-19.

Ryiadi, Nayda Al-khowarizmi, Ni Nyoman Kerti Yasa.(2016). "Kemampuan Inovasi Memediasi Pengaruh Orientasi Kewirausahaan Terhadap Kinerja Produk IMK Sektor Industri Makanan di Kota Denpasar".E - Jurnal Manajemen Unud, 5 (3), hal.1915-1941.

Sugiyono.(2018). Metode Penelitian Kuantitatif.Bandung: Alfabeta.

Syukron, Muhammad Zidni, Ngatno. (2016).“Pengaruh Orientasi Pasar Dan Orientasi Kewirausahaan Terhadap Inovasi Produk Dan Keunggulan Bersaing UMKM Jenang Di Kabupaten Kudus".Jurnal Administrasi Bisnis, 5 (1), hal.24-34.

Wardana, Wisnu. (2016). Jewelry of Bali. Denpasar: Biro Promosi dan Pengembangan Pariwisata Budaya.

Wardi, Yunia, Perengki Susanto, Nor Liza Abdullah. (2017). “Orientasi Kewirausahaan pada Kinerja Usaha Kecil dan Menengah (UKM) Sumatera Barat: Analisis Peran Moderasi dari Intensitas Persaingan, Turbulensi Pasar dan Teknologi".Jurnal Manajemen Teknologi, 16 (1), hal.46-61.

Wibowo, Dimas Hendika, Zainul Arifin, Sunarti. (2015). “Analisis Strategi Pemasaran Untuk Meningkatkan Daya Saing UMKM (Studi Pada Batik Diajeng Solo)".Jurnal Administrasi Bisnis (JAB), 29 (1), hal.59-66. 